\title{
Modeled construction and operating costs of different ventilation systems for lactating dairy cows
}

\author{
M. R. Mondaca* and N. B. Cook \\ School of Veterinary Medicine, University of Wisconsin-Madison, Madison 53706
}

\section{ABSTRACT}

The objectives were to compare capital costs of building and installation of 7 ventilation systems for adult lactating dairy cow housing and evaluate the energy use and operating cost between systems. A cost model comprising stochastic and parametric modules was created to estimate the number of fans operating each day based on temperature set points; annual profiles of daily maximum, minimum, and average temperatures; ramping functions to transition between seasons; and weather data from 7 locations in the United States. Costs were described as US\$ per stall per year and operating costs as US\$ $(\mathrm{kW} \cdot \mathrm{h})$ per stall per year. Building costs amoritized over 10 yr ranged from $\$ 246$ to $\$ 318$, where a 16-row cross-ventilated design had the minimum cost and a hybrid design incorporating elements of tunnel and natural ventilation had the maximum cost. Lowering the summer temperature set point from 22.2 to $18.0^{\circ} \mathrm{C}$ to potentially improve heat abatement for high-producing cows increased cost by $\$ 10.10$ (101.0 $\mathrm{kW} \cdot \mathrm{h}$ ). On average, an exponential ramping function for transitioning between seasons cost $\$ 55.40(554 \mathrm{~kW} \cdot \mathrm{h})$ compared with $\$ 61.40(614 \mathrm{~kW} \cdot \mathrm{h})$ for a linear function. A tunnel barn ranged from $\$ 79.40(794 \mathrm{~kW} \cdot \mathrm{h})$ to $\$ 212.30(2123 \mathrm{~kW} \cdot \mathrm{h})$, and a natural design ranged from $\$ 32.60(326 \mathrm{~kW} \cdot \mathrm{h})$ to $\$ 81.80(818 \mathrm{~kW} \cdot \mathrm{h})$ in operating costs due to fan selection alone. Cross-ventilated barns benefitted from economies of scale and had similar operating costs as naturally ventilated barns in larger facilities. On average, mechanical systems cost twice as much to operate as natural systems, and operating costs in hotter US climates were approximately double those in milder climates. Selecting a fan with low energy efficiency can increase the operating cost of any ventilation system approximately 2 -fold, making fan choice a critical design element.

Key words: dairy housing, ventilation, energy use, economic model

Received March 5, 2018.

Accepted September 6, 2018.

*Corresponding author: mondacaduart@wisc.edu

\section{INTRODUCTION}

To maintain welfare-friendly housing conditions, it is important to provide cows with a clean and cool microenvironment. Ideally, a ventilation system provides this by introducing fresh air year round and by creating fast-moving air in the cows' resting area for summertime cooling.

Dairy producers in North America are confronted with multiple options for ventilating adult lactating cow dairy facilities, including both natural and mechanical ventilation systems. Brotzman et al. (2015) found that $90 \%$ of facilities in Wisconsin with more than 200 cows were naturally ventilated. However, wind shadows created by nearby buildings, land availability, barn orientation, and other factors can limit the function of natural ventilation systems, leading to a growing interest in mechanical systems among dairy producers. Unlike natural ventilation, mechanical ventilation completely relies on fans to provide an adequate ventilation rate and appropriate air speeds in the animal-occupied space.

Current predictions of the direct energy demand of dairy production are usually based on the analysis of farm energy bills, which is inaccurate because it may include other farm activities unrelated to milk production (Todde et al., 2017). Todde et al. (2017) concluded that future research should focus on developing models that are able to predict the distribution of electricity and diesel consumption in relation to different farm operations. Of the few studies to break down energy use into categories, Ludington and Johnson (2003) found that ventilation accounted for $22 \%$ of the energy use in freestall barns. Ludington and Johnson (2003) defined energy savings for all aspects of milking dairy cows except ventilation, where no energy conservation methods were defined at all. This is likely because no consensus exists in the industry about what ventilation strategy works best for the cows' comfort or what the regional energy use or operating cost of each system is (Stowell et al., 2003). Many existing recommendations date back to a 10-yr summary of psychroenergetic dairy cattle research at the University of Missouri, summa- 
rized by Yeck and Stewart (1959), at a time when milk production per cow was much lower than it is currently. In practice, barns are now constructed far exceeding current ventilation standards and recommendations (Stowell et al., 2003), with little regard to an assessment of energy use and building and operating costs. As such, the objectives of this study were to compare the capital costs of building and installing 7 ventilation systems for adult lactating dairy cow housing and to evaluate the energy use and ventilation operating cost changes between systems in 7 US locations to inform the dairy industry of available ventilation options and their costs.

\section{MATERIALS AND METHODS}

\section{Facility Design}

The decisions used to create the ventilation systems investigated in this study mirrored the decision-making process currently used by dairy producers in constructing a new facility for adult lactating dairy cattle across the United States. The outcome describes the cost per stall per year of building, installing, and operating a ventilation system. For comparison purposes across the different systems, consistency was ensured by developing a uniform pen of 126 stalls, which served as a core building block for all facilities. The pens were arranged in a head-to-head 2-row stall configuration (Figure 1) and all stalls were $1.2 \mathrm{~m}$ wide on center on a 5.2-m-long platform, with 4.3-m-wide crossovers placed every 21 stalls. The pens had 4.0-m-wide feed alleys and 3.0-mwide rear alleys. This pen size and layout are consistent with the average maximum pen size observed across larger freestall facilities surveyed by Brotzman et al. (2015) and is in line with the design recommendations laid out by The Dairyland Initiative (2016).

Based on a review of the different ventilation options currently being installed in the Midwestern United States, 7 ventilation systems worthy of investigation and representative of most currently used designs were identified. These ventilation systems included 2 naturally ventilated barns that were compared with
5 mechanically ventilated barns, which consisted of 3 tunnel-ventilated and 2 cross-ventilated designs (Figure 2 ). The barn footprint was calculated based on the total area of the facility including space between barns, when applicable (Figure 2). These systems were designed in part by following the current recommendations in Holmes et al. (2013) and by communicating with leading agricultural ventilation providers regarding their approach to designing state-of-the-art ventilation systems. Holmes et al. (2013) suggested air speeds of 1 to $2 \mathrm{~m} / \mathrm{s}$ moving past the cow bodies as well as providing 800,289 , and $85 \mathrm{~m}^{3} / \mathrm{h}$ of fresh air for a $635-\mathrm{kg}$ cow in hot, mild, and cold weather, respectively. Alternative ventilation rates are listed as 4 air changes per hour (ACH) for winter ventilation and 40 to $60 \mathrm{ACH}$ for summer ventilation. By contrast, summer ventilation in new barns is currently being designed in the industry for higher ventilation rates $(60-100 \mathrm{ACH})$ and at higher cross-sectional air speeds of 2.2 to $3.6 \mathrm{~m} / \mathrm{s}$ (Bucklin et al., 2009) or higher air flow rates of 1,700 to 2,500 $\mathrm{m}^{3} / \mathrm{h}$ per cow. Cross-ventilated facilities are suggested to provide 30 to $60 \mathrm{ACH}$ during the summer, and they were found to provide adequate fresh air to prevent detectable gaseous compounds (Smith et al., 2007).

The naturally ventilated facilities consisted of two 4-row barns in an $\mathrm{H}$ configuration, each containing 4 uniform pens of cows with a 6 -m-wide drive-through feed lane. The barns were spaced $30 \mathrm{~m}$ apart and were connected by a 6 -m-wide breezeway. Each barn was 195 $\mathrm{m}$ long and $33 \mathrm{~m}$ wide with $4.3-\mathrm{m}$ sidewalls fitted with retractable sidewall curtains. The roof was a 4:12 pitch with a ridge opening of $0.5 \mathrm{~m}$. The total barn footprint was $18.6 \mathrm{~m}^{2} /$ stall, calculated as the total space taken by the barns, including any space between them. Air speed within the barn was increased using panel fans located $2.1 \mathrm{~m}$ above the stalls (OSHA, 1970) and spaced $14.6 \mathrm{~m}$ (NAT1) or $7.3 \mathrm{~m}$ (NAT2) apart. The natural ventilation designs were selected to compare 2 common fan placements in naturally ventilated barns. Fans are typically spaced at 5 to 10 fan diameters apart, which was rounded to 7.3 to $14.6 \mathrm{~m}$ (24-48 feet) based on common roof support post spacing, where the fans are often secured.

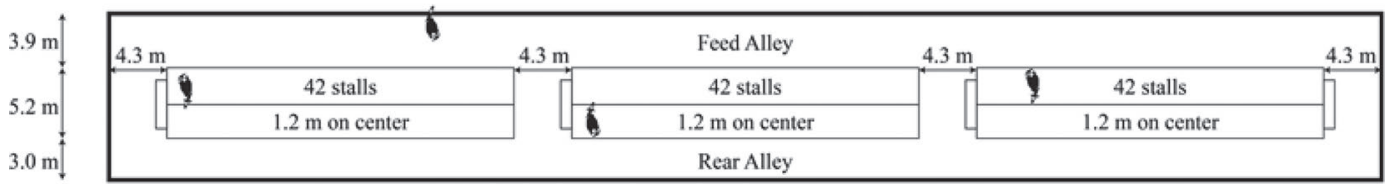

Figure 1. Pen design characteristics used as a building block across all ventilation systems. 
The tunnel-ventilated facilities had a similar layout to the naturally ventilated systems. They consisted of two 4-row barns in an $\mathrm{H}$ configuration, each containing 4 uniform pens of cows with a 6 -m-wide drive-through feed lane. The barns were spaced $18 \mathrm{~m}$ apart and were connected by a 6 -m-wide breezeway. Each barn was 195 $\mathrm{m}$ long and $33 \mathrm{~m}$ wide with 4.0-m sidewalls, and only a portion of the sidewalls was equipped with retractable curtains close to the endwall opposite to the fans to provide an air inlet. The roof had a 2:12 pitch with a closed ridge. Three variations of tunnel barns were created, all with the same barn footprint of $16.3 \mathrm{~m}^{2} /$ stall. The first variation (TUN60) was designed to provide a ventilation rate of $60 \mathrm{ACH}$ and $3.3 \mathrm{~m} / \mathrm{s}$ cross-sectional air speeds with exhaust fans installed on the endwall and adjacent sidewalls. Producers and builders have, however, noted a large variation in air speeds across the lanes compared with the cow's resting area (Gooch and Stowell, 2003). Therefore, the design of the second variation (TUN40) was based on reducing the design air speed across the barn but increasing the air speed in the resting area by incorporating the NAT2 system of panel fans above the stalls while operating at $40 \mathrm{ACH}$. The third variation, the hybrid facility (HYB40), was designed with the same ventilation system as the TUN40 barn but used 1.83-m louvered fans above the stalls spaced at the manufacturer-recommended $18 \mathrm{~m}$ apart as well as 11 ridge fans and cupolas to assist with

2-barn H-configuration (NAT1, NAT2, TUN60, TUN40, and HYB40)

1-barn (8CRO and 16CRO)
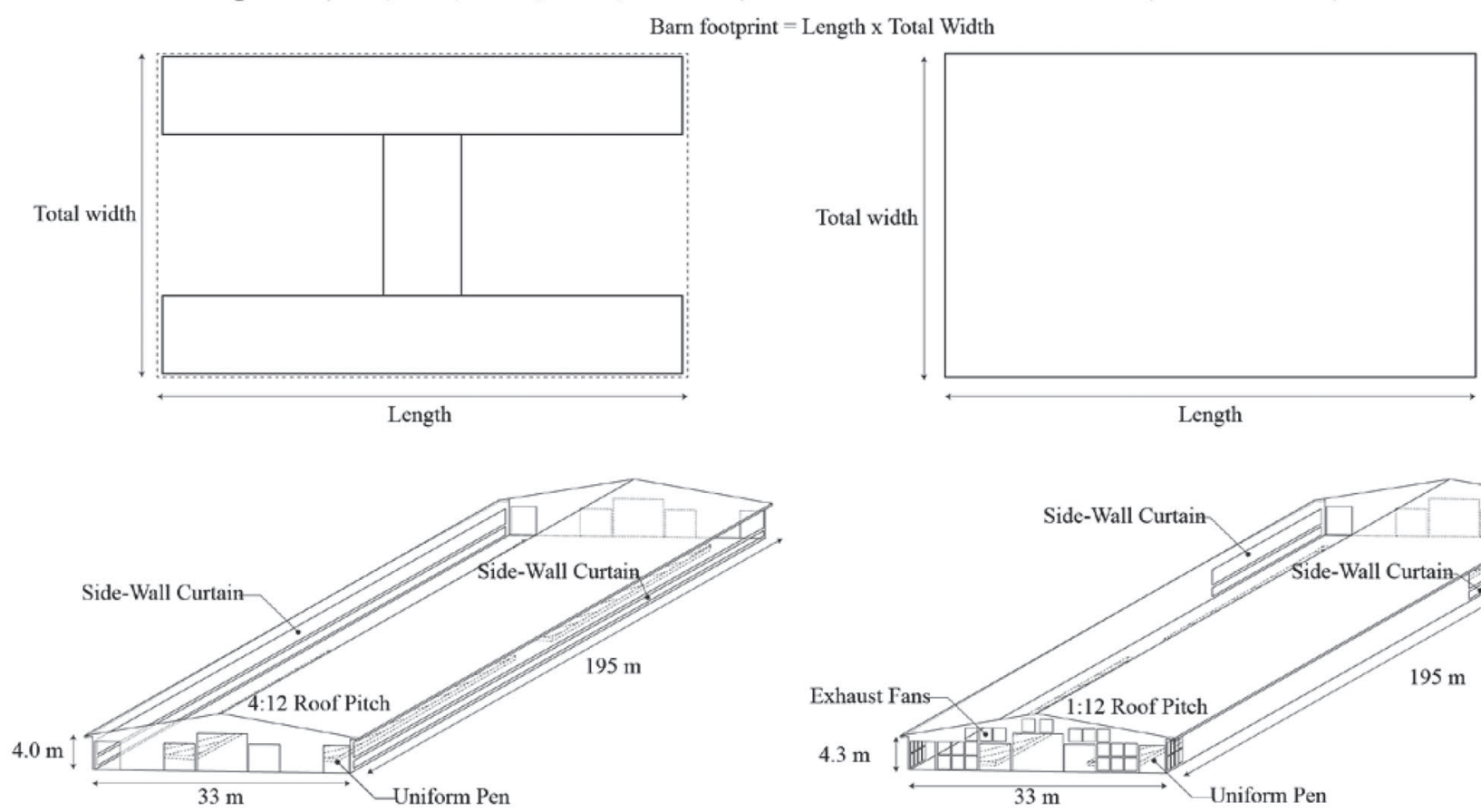

NAT2 - Panel fans over stalls every $7.3 \mathrm{~m}$ (24 ft)

NAT1 - Panel fans over stalls every 14.6 m (48 ft)
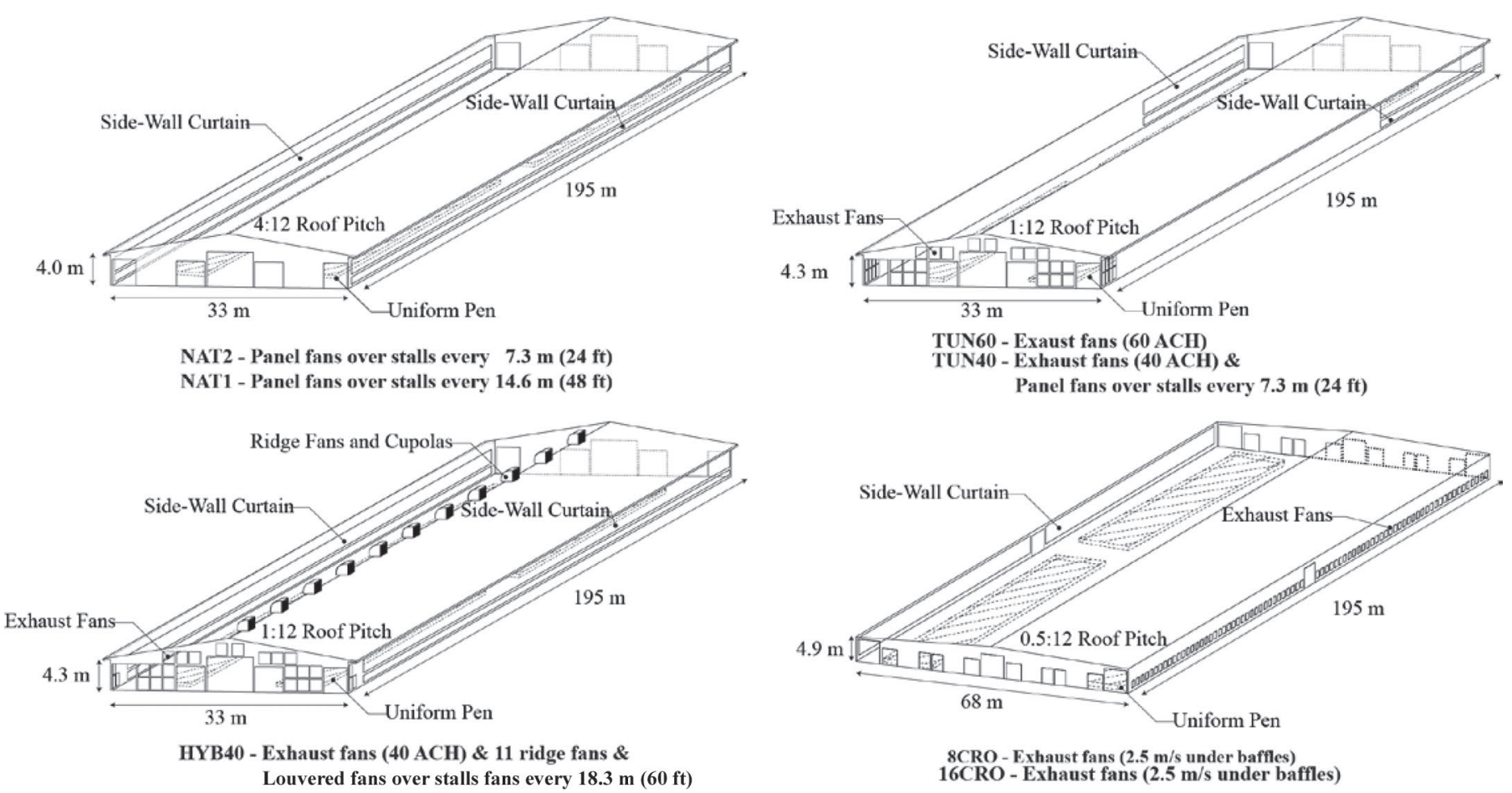

Figure 2. Barn designs for 7 ventilation systems: natural (NAT1 and NAT2), tunnel (TUN60 and TUN40), hybrid (HYB40), and crossventilation (8CRO and $16 \mathrm{CRO}) . \mathrm{ACH}=$ air changes per hour. 
the movement of air out through the ridge during cold $\left(<4.4^{\circ} \mathrm{C}\right)$ temperatures. The HYB40 version went a step further to completely transition from tunnel ventilation in the mild $\left(>4.4^{\circ} \mathrm{C}\right)$ and summer $\left(>20.0^{\circ} \mathrm{C}\right)$ temperatures to a cupola system that uses fans to help draw air out through the ridge in the winter $\left(<4.4^{\circ} \mathrm{C}\right)$. The hybrid system required sidewall curtains to be divided and to run along the entire barn length to act as an inlet in colder temperatures, whereas the other tunnel designs had a curtain inlet system at one end and solid panels for the remainder of the side walls.

A cross-ventilated facility comprised a single 8-row barn (8CRO) with 8 uniform pens of cows with three 6-m drive-through feed lanes (2 at the outside edges and 1 in the middle of the barn). The barn was $195 \mathrm{~m}$ long and $68 \mathrm{~m}$ wide with 4.9 -m-high sidewalls. The roof pitch was 0.5:12 with a closed ridge, equipped with baffles over the head-to-head stalls down to a height of 2.1 $\mathrm{m}$ above the stall surface. Another version (16CRO) was similar but had 16 uniform pens and 5 feed lanes and was designed for the principal purpose of examining the current trend in the industry toward wide-body barns with multiple rows of stalls - in some instances with 24 rows of stalls or more. The baffles were placed above each pen between the head-to-head stalls for a total of 4 baffles on the 8CRO system and 8 baffles on the 16CRO system. The barn footprint was 13.3 and $12.9 \mathrm{~m}^{2} /$ stall for the $8 \mathrm{CRO}$ and $16 \mathrm{CRO}$ systems, respectively. The ventilation was designed to achieve air speeds of $2.5 \mathrm{~m} / \mathrm{s}$ under the baffles, provided by exhaust fans installed along the sidewall for both the 8CRO and 16CRO barns. This comparison was selected to highlight the economic advantage of doubling the size of the facility while maintaining a $2.5 \mathrm{~m} / \mathrm{s}$ cross-sectional air speed without increasing the number of fans. Previous studies have suggested designing cross-ventilated barns by evaluating inlet speeds and the pressure drop at each baffle (Smith et al., 2007). However, the crossventilated facilities were designed using $2.5 \mathrm{~m} / \mathrm{s}$ as a compromise between recommendations by the industry and previous peer-reviewed studies (Smith et al., 2016). The facilities had ventilation rates of 53 and $24 \mathrm{ACH}$ for the $8 \mathrm{CRO}$ and $16 \mathrm{CRO}$ systems, respectively, which are in line with the high and medium ventilation rates (50.0 and 33.7 ACH, respectively) evaluated in Smith et al. (2007).

\section{Ventilation Building and Installation Costs}

For all but 1 design option (16CRO housed 2,016 stalls), the facilities housed 1,008 stalls, and all were presented to a Wisconsin construction company (Bayland Buildings Inc., Hobart, WI) so that the design could be critiqued and an accurate cost of construc- tion could be obtained. Estimates for fan and electrical installation costs were quoted by a fan manufacturing company (J\&D Manufacturing, Eau Claire, WI). Probability distribution functions (PDF) were generated for fan capital and installation costs; the specifics are discussed in the stochastic module. The final costs did not include land excavation, manure handling, milking parlor, holding area, backup generator, or costs of upkeep or repairs of the barn or the ventilation systems.

At this facility size, each of the 7 designs is expected to have a backup generator capable of operating the parlor hardware and software requirements to milk the cows. A key advantage of the natural and hybrid system is the ability to open the curtains and naturally ventilate in times when emergency ventilation is needed due to power failure. Although not modeled in this study, mechanical ventilation facilities without sidewalls (TUN60, TUN40, 8CRO, and 16CRO) would need to increase the necessary generator capacity by around $20 \%$ based on the distribution of energy use in freestall operations (Ludington and Johnson, 2003). Ventilation capital costs were amortized over a $10-y r$ loan period at an interest rate of $4.25 \%$ annually, with the final outcome being the total cost of construction and installation per stall per year for the ventilation system. These designs are typical of those currently being installed in the United States for lactating dairy cow freestall facilities.

\section{Ventilation Operating Costs}

The operating costs are based exclusively on the fan electrical operating costs. The full cost model was summarized in a pseudoprogramming flow diagram. The inputs for the models were the characteristics of each ventilation system to be evaluated: number of barns, the barn volume, the winter (4 ACH for all systems) and summer ventilation rates, and the winter set point $\left(4.4^{\circ} \mathrm{C}\right.$ for all systems) and the summer temperature set points.

Stochastic Module. The stochastic module used a combination of PDF as uniform (U), symmetrical triangular $(\mathbf{T})$, logistic $(\mathbf{L o})$, or normal $(\mathbf{N})$-indicated as $\mathrm{U}(a, b), \mathrm{T}(P=0.5, a, h), \mathrm{Lo}\left(\mu, \sigma^{2}\right)$, and $\mathrm{N}\left(\mu, \sigma^{2}\right)$, respectively - as described in Balakrishnan and Nevzorov (2003), where $a, b$, and $h$ are constants; $\mu$ is the location parameter; and $\sigma$ is the scale parameter. The PDF were created using the fitdistrplus package (DelignetteMuller and Dutang, 2015) in $\mathrm{R}$ version 3.3.2 ( $\mathrm{R}$ Core Team, 2016). The PDF for panel fan capacity $\left(\mathrm{m}^{3} / \mathrm{h}\right)$ was $\mathrm{U}(19,210,38,981)$, ventilation efficiency rating (VER; $\mathrm{m}^{3} / \mathrm{h}$ per $\left.\mathrm{W}\right)$ was $\mathrm{U}(20.7,28.8)$, fan capital cost $(\$ /$ fan $)$ was $\mathrm{U}(584,998)$, and fan wiring cost was $\mathrm{T}(0.5$, $275,350)$. The PDF for exhaust fan capacity $\left(\mathrm{m}^{3} / \mathrm{h}\right)$ 
was $\mathrm{N}(23,830,3,741)$, VER was $\mathrm{N}(18.3,2.9)$, fan capital cost $(\$ /$ fan $)$ was $\operatorname{Lo}(1,354,174)$, and fan wiring cost was $\mathrm{T}(0.5,300,400)$. The fan's physical installation cost was modeled as $\mathrm{T}(0.5,45,120)$, and energy price $(\$ / \mathrm{kW} \cdot \mathrm{h})$ was modeled as a uniform PDF $\mathrm{U}(0.05,0.30)$. The fan capacity, VER, installation costs, and capital costs were generated by pooling publicly available data from BESS Laboratories (University of Illinois, UrbanaChampaign), various industry publications, and quotes from fan dealers. Exhaust fans of 127- to 152-cm blade diameter were considered and had a minimum of 18,689 $\mathrm{m}^{3} / \mathrm{h}$ and $14.6 \mathrm{~m}^{3} / \mathrm{h}$ per $\mathrm{W}$, a maximum of $62,812 \mathrm{~m}^{3} / \mathrm{h}$ and $46.6 \mathrm{~m}^{3} / \mathrm{h}$ per $\mathrm{W}$, and a total of 218 samples. Panel fans of 122- to $132-\mathrm{cm}$ blade diameter were considered and had a minimum of $32,637 \mathrm{~m}^{3} / \mathrm{h}$ and $35.2 \mathrm{~m}^{3} / \mathrm{h}$ per $\mathrm{W}$, a maximum of $66,229 \mathrm{~m}^{3} / \mathrm{h}$ and $48.9 \mathrm{~m}^{3} / \mathrm{h}$ per $\mathrm{W}$, and a total of 18 samples. The capital cost of exhaust fans ranged from $\$ 841$ to $\$ 2,621$ with 49 samples, and panel fans ranged from $\$ 584$ to $\$ 998$ with 15 samples. The 183-cm louvered fans had only 1 option and did not have stochastic variability on rating or cost in the model. The range in energy price was large and meant to represent global variations in $\$ / \mathrm{kW} \cdot \mathrm{h}$ ratings from 0.05 to $0.30 \$ / \mathrm{kW} \cdot \mathrm{h}$.

The stochastic module sampled the fan's capacity and recalculated the required number of fans to meet each mechanical system's summer ventilation requirements. The model then sampled the PDF for fan capital costs, fan wiring costs, and installation costs, and the number of fans was used to calculate the total capital costs from the ventilation systems.

Each ventilation system iteration has a stochastic system rating. The system rating was defined as the total $\mathrm{kW} \cdot \mathrm{h}$ for each system. This means that each time the PDF are sampled by the stochastic module, a new system rating is defined for each ventilation system with a different $\mathrm{kW} \cdot \mathrm{h}$ used to estimate the electrical energy use (Figure 3).

Parametric Module. The parametric module determined the number of days each system operated and the intensity (number of fans) it was operating under using different ramping functions, annual temperature profiles, location temperature variation, and summer temperature set points. Seven different US locations were selected to compare operational costs of the 7 ventilation systems. These locations were Arizona, California, Florida, Minnesota, Pennsylvania, Washington, and Wisconsin. Arizona and Florida were selected for their challenging thermal environments and year-round risk for heat stress, whereas the others were selected for being among the top 10 dairy-producing states as well as their geolocation and weather. Within each of these locations, the model used historical weather data
(6 yr in this study) and used the 6-yr averages for daily maximum, mean, and minimum temperatures (NOAA, 2017). Temperature data were stored in a 3-dimensional array consisting of varying temperature profiles (minimum, average, maximum), location, and Julian day (Figure 4).

Temperature sensors are typically used for controlling ventilation and heat abatement systems. However, the temperature-humidity index (THI), not temperature, has been used as a rule of thumb to determine when cows will begin to experience heat stress. Armstrong (1994) developed a chart that suggested that at a THI of 72 , high-producing dairy cows will begin experiencing heat stress. Collier et al. (2011) re-evaluated the suggested THI ranges and instead concluded that a THI of 68 should be the new threshold for heat stress and that cows producing above $35 \mathrm{~kg} / \mathrm{d}$ would require additional cooling when the minimum daily THI was 65 or greater. The current rule of thumb for summer temperature set point is $20.0^{\circ} \mathrm{C}$; however, because milk production per cow is increasing (USDA ERS, 2017), the industry is pushing the summer set point down to $18.3^{\circ} \mathrm{C}$ (Bailey et al., 2016) or lower. To test the effect that the temperature set point has on operating costs, 5 summer temperature set points of 16.7, 18.3, 20.0, 22.2 , and $23.9^{\circ} \mathrm{C}$ were used in our model. Table 1 shows a summary of the days operating at winter $\left(\leq 4.4^{\circ} \mathrm{C}\right)$, transitional, and summer (at $\geq 20.0^{\circ} \mathrm{C}$ ) set points to demonstrate the variation in operating time for each of the 7 locations chosen.

Humidity was not included because current systems rarely use relative humidity to control fan function. For each summer temperature set point, 3 ramping functions (linear, staged, and exponential) were created to determine the transitional periods between summer and winter temperature set points. Finally, Equations 1 and 2 were used to calculate the total operating cost for the year under specific conditions:

$$
\begin{gathered}
\text { Natural } \operatorname{costs}_{k}=Y \times B^{k} \sum_{d=1}^{365} 24 F_{n}^{i} F_{k W h}^{i} e \\
\text { Mechanical } \operatorname{costs}_{k}^{j}=Y \times B^{k} \sum_{d=1}^{365} 24 F_{n}^{i j} F_{k W \cdot h}^{i} e,
\end{gathered}
$$

where $i$ is the fan type (panel, exhaust, or louvered), $k$ is the ventilation system, $j$ is the ramping function (linear, staged, or exponential), $Y$ is the number of years the system operates, $B$ is the number of barn, $e$ is the energy price, $F_{k W \cdot h}$ is the fan's power consumption per hour, $F_{n}$ is the number of fans operating each day, and $d$ is Julian day.

To find a reasonable stopping point, the cost of the 8CRO system was stochastically iterated 3,700 times 
and 109 times under a single set of parametric conditions. A Welch 2-sample $t$-test was used to compare the means, and an $F$-test was used to compare the variances in the data. The Welch $(P=0.8)$ and $F(P=0.94)$ tests failed to reject the null hypothesis. Therefore, the systems were evaluated for 109 stochastic iterations (system rating and energy price). Within each stochastic iteration (Figure 3), the parametric module varied for a total of 2,205 annual cost values corresponding to (1) 5 summer temperature set points, (2) 7 locations, (3) 3 ramping functions between winter and summer ventilation, (4) 3 yearly temperature profiles, and (5) 7 different ventilation systems for a total of 240,345 observations. Mean, median, minimum, and maximum costs were found using the summary function in $\mathrm{R}$ version 3.3.2 ( $\mathrm{R}$ Core Team, 2016). No milk production losses, health effects due to poor ventilation, or other heat stress-related effects were considered in the cost model.

\section{RESULTS AND DISCUSSION}

\section{Capital Costs}

The building and ventilation capital costs are stated in US\$ per stall per year when amortized over $10 \mathrm{yr}$.

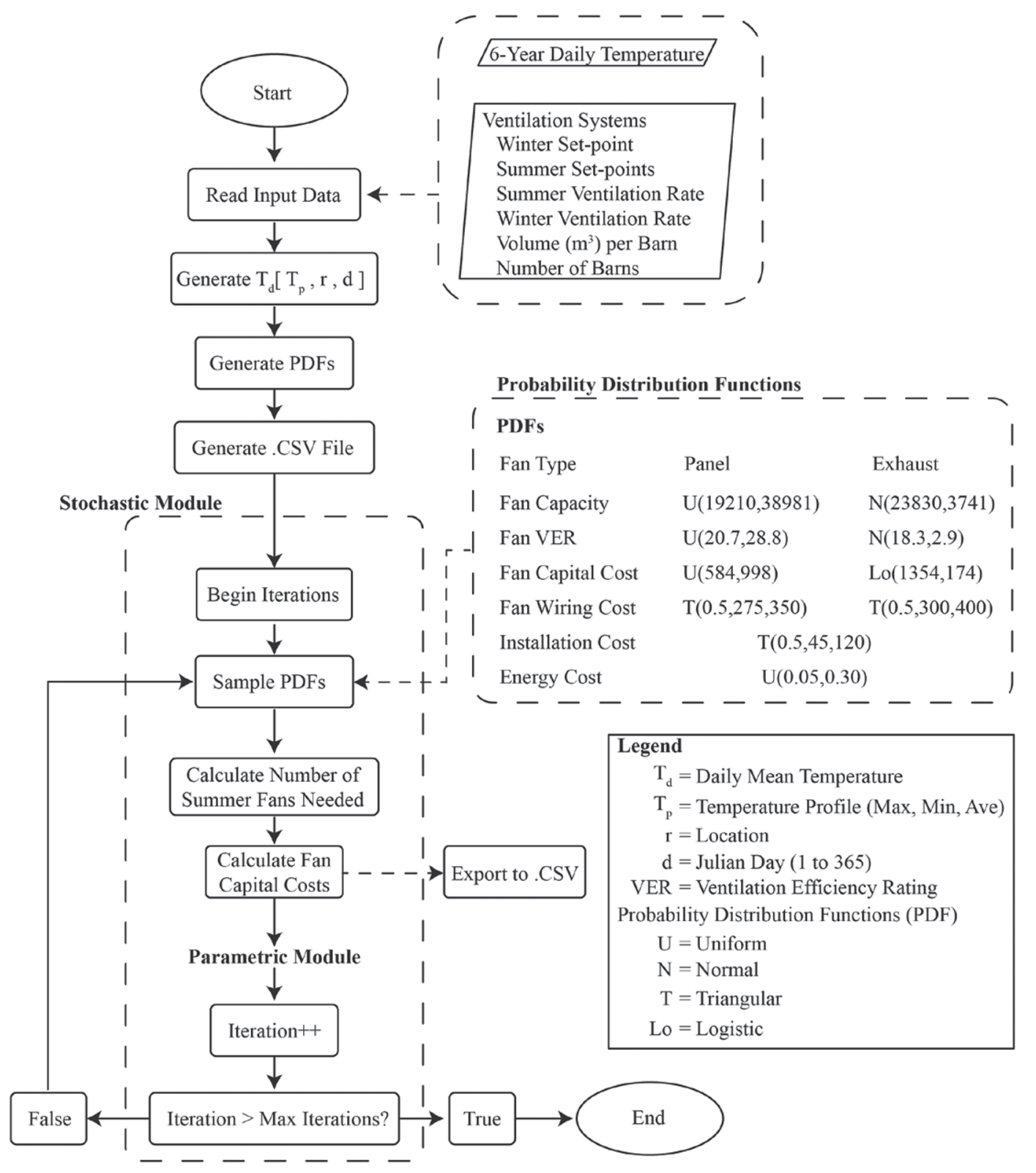

Figure 3. Cost model pseudoprogramming diagram showing the probability distribution functions (PDF) and inputs required by the model. 
$\mathrm{T}_{\mathrm{d}}=$ Daily Mean Temperature

$\mathrm{T}_{\mathrm{w}}=$ Winter Temperature Set-point

$\mathrm{T}_{\mathrm{p}}=$ Temperature Profile (Max, Min, Ave)

$\mathrm{T}_{\text {set }}=$ Temperature Profile (Max, Min, Ave)

$\mathrm{T}_{\text {set }}=$ Summer Set-points $\left(16.7,18.3,20.0,22.2,23.9^{\circ} \mathrm{C}\right)$

\section{Legend}

$\mathrm{ACH}=$ Air Changes per Hour

$\mathrm{V}_{\mathrm{s}}=$ Summer Ventilation Rate

$\mathrm{V}_{\mathrm{w}}=$ Winter Ventilation Rate

$\mathrm{d}=$ Julian Day (1 to 365)

$r=$ Location

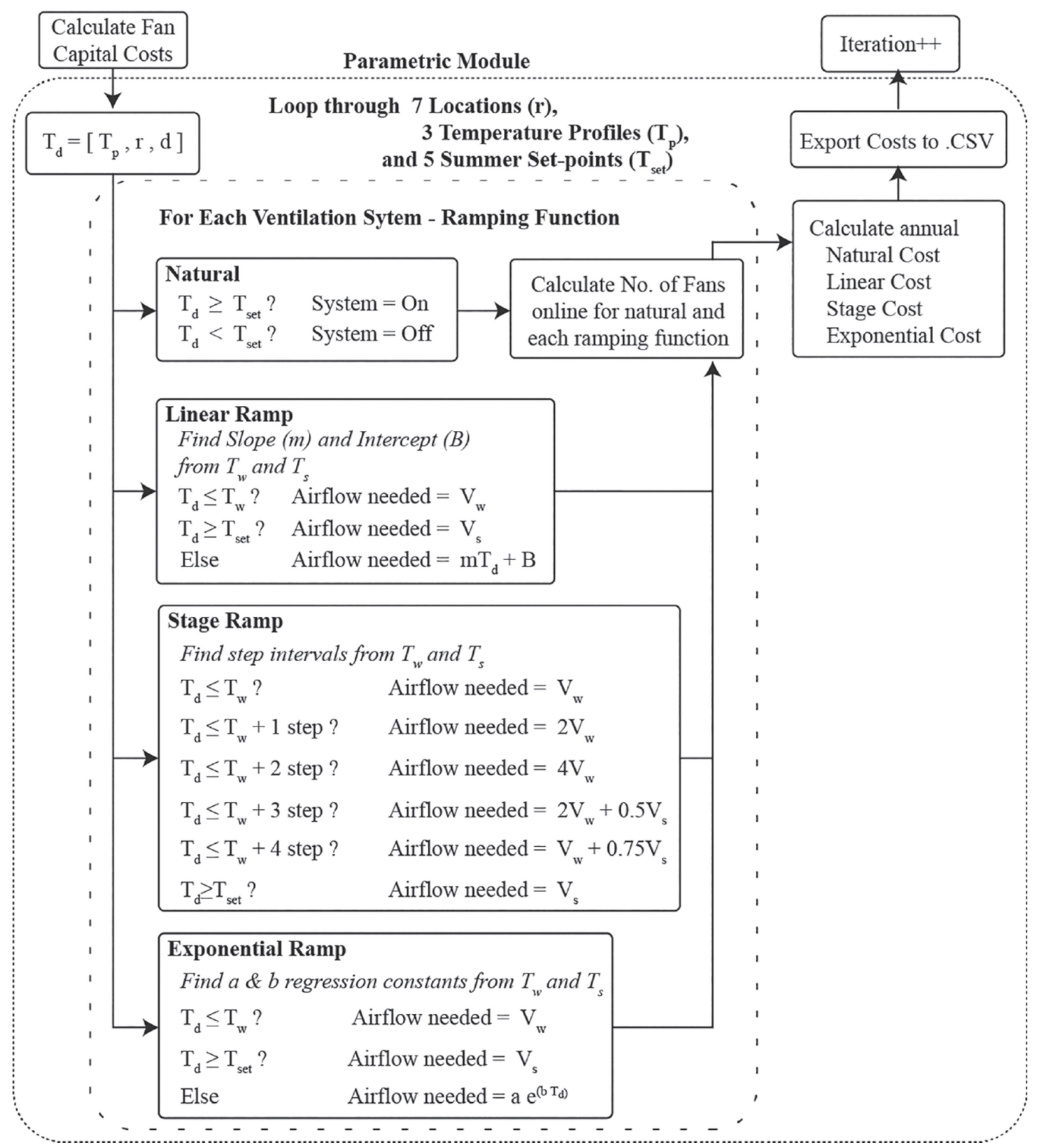

Figure 4. Parametric cost module pseudoprogramming diagram showing the sensitivity analysis conditions (location, temperature profile, summer set point, and ramping functions) to calculate annual operating costs. Max $=$ maximum; Min $=$ minimum; Ave $=$ average. $a=$ function constant for exponential regression, $\mathrm{e}=$ base of the natural logarithm; $\mathrm{b}=$ function constant for exponential regression. 
The costs per stall per year were $\$ 285$ for NAT1, $\$ 289$ for NAT2, $\$ 291$ for TUN60, $\$ 295$ for TUN40, $\$ 318$ for HYB40, $\$ 295$ for $8 \mathrm{CRO}$, and $\$ 246$ for $16 \mathrm{CRO}$. The total cost per stall for all systems ranged from $\$ 2,460$ to $\$ 3,180$ per stall. These costs fall within the estimates made by Kammel (2015) and are similar to the economic evaluation by Ferreira et al. (2016), which assumed that the barn costs were $\$ 2,500$ per stall when not including electrical components.

The barn footprint per stall for each design is shown in Figure 2; the smallest footprint was $12.9 \mathrm{~m}^{2} /$ stall for the 16CRO system. The barn footprints for the tunnel ventilation systems were $16.3 \mathrm{~m}^{2} /$ stall and $18.6 \mathrm{~m}^{2} /$ stall for the natural ventilation systems. The low-profile cross-ventilated barns with 2,016 stalls had the least cost per stall and the lowest barn footprint when compared with tunnel-ventilated and naturally ventilated barns. However, the barn was designed for $2.5 \mathrm{~m} / \mathrm{s}$ below the baffles and suffered from a slightly low ventilation rate $(24 \mathrm{ACH})$ compared with current recommendations. Meanwhile, the HYB40 system was the most costly, but it had the greatest flexibility to accommodate different weather conditions, and it was only $\$ 34$ per stall per year more expensive to construct than the NAT1 barn.

Overall, construction costs were similar across the range of different designs. Therefore, the authors advise producers deciding on a new facility's ventilation system to weigh other factors, such as the barn orientation, footprint per stall, cow flow, lighting, manure handling, and so on, over the cost of building a specific type of barn ventilation system.

\section{Operating Costs: Stochastic Module}

The cost of operating the systems at maximum capacity year round (all fans online $24 \mathrm{~h} / \mathrm{d}$ for $365 \mathrm{~d} /$ yr), with changes due to system type and fan variance for all conditions, is shown in Figure 5. Evaluating the system at maximum capacity (operating the system year round) removes any cost changes due to parametric components (temperature set points, temperature profile, ramping function, and location). Even though

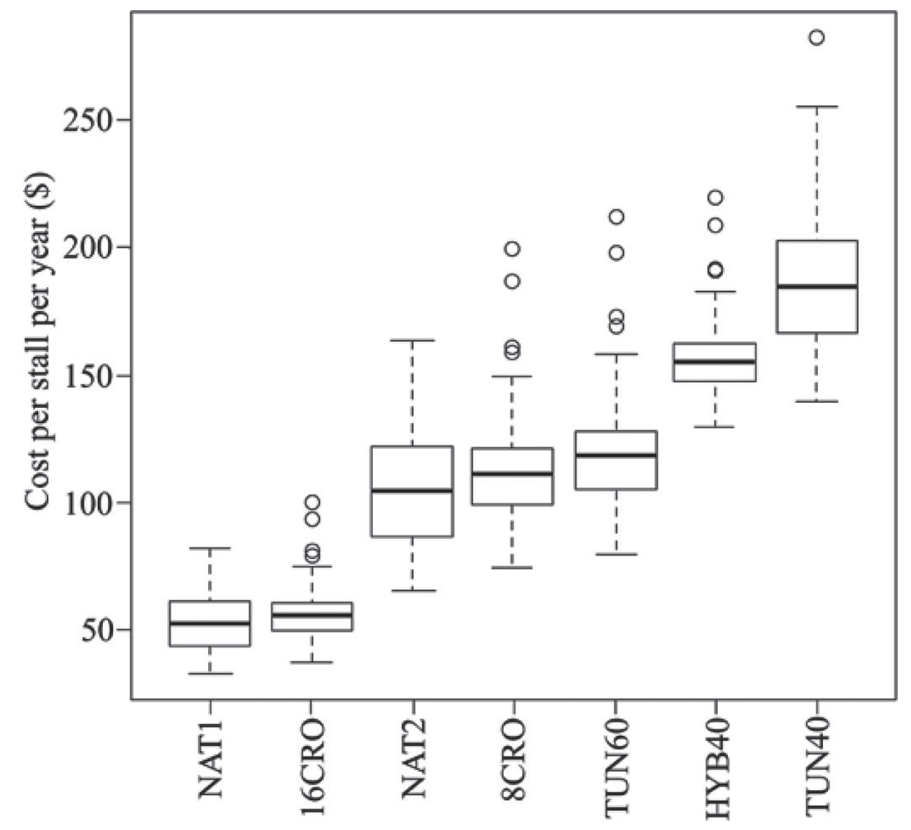

Figure 5. Box and whiskers diagram showing the median (bars), third and first quartile (top and bottom of the box, respectively), maximum and minimum (top and bottom of the dashed line capped by a horizontal line), and suspected outliers (values greater 1.5 times the difference between the third quartile and the maximum) of the operating costs changes due to fan stochastic effects (excluding energy price); systems are shown operating at maximum capacity $(24 \mathrm{~h} / \mathrm{d}$ for $365 \mathrm{~d} / \mathrm{yr}$ ). Natural ventilation with fans spaced every $14.6 \mathrm{~m}$ (NAT1) and $7.3 \mathrm{~m}$ (NAT2). Tunnel ventilation at 60 (TUN60) air changes per hour (ACH) and 40 (TUN40) ACH with panel fans every $7.3 \mathrm{~m}$. Hybrid (HYB40) ventilation (40 ACH) using louvered fans every 18.3 $\mathrm{m}$. Eight-row (8CRO) and 16-row (16CRO) cross-ventilated systems designed for $2.5 \mathrm{~m} / \mathrm{s}$ below the baffle.

energy price had a commanding effect on the operating costs, the producer seldom has control over the energy price they must pay, and the factor acts as a direct multiplier to the cost. For example, the NAT2 design had a range in maximum energy use of $\$ 65.30$ (653 $\mathrm{kW} \cdot \mathrm{h})$ to $\$ 163.60(1,636 \mathrm{~kW} \cdot \mathrm{h})$ per stall per year at an energy price of $\$ 0.10 / \mathrm{kW} \cdot \mathrm{h}$, which increased to $\$ 39.47$ to $\$ 379.30$ when energy price was allowed to vary.

All systems had a wide range in maximum operating cost due to fan selection. For example, the cost per stall

Table 1. Number of days operating under winter, transitional, and summer ventilation rates for 7 locations in the United States based on 6-yr average daily temperature $\left(T_{d}\right)$ profiles

\begin{tabular}{lccc}
\hline Location & Winter $\left(\mathrm{T}_{\mathrm{d}} \leq 4.4^{\circ} \mathrm{C}\right)$ & Transitional & Summer $\left(\mathrm{T}_{\mathrm{d}} \geq 20.0^{\circ} \mathrm{C}\right)$ \\
\hline Jacksonville, Florida & 0 & 168 & 197 \\
Phoenix, Arizona & 0 & 128 & 237 \\
Fresno, California & 0 & 198 & 167 \\
Madison, Wisconsin & 128 & 153 & 84 \\
Spokane, Washington & 138 & 195 & 32 \\
Allentown, Pennsylvania & 102 & 159 & 104 \\
St. Cloud, Minnesota & 149 & 146 & 70 \\
\hline
\end{tabular}


per year for the TUN60 system ranged from $\$ 79.35$ to $\$ 212.30$ from the minimum to maximum, with a median of $\$ 118.30$; the increase of $267 \%$ between the minimum and maximum was due to fan selection alone. For all of the mechanical systems, choice of fan was the main reason for the considerable variation in energy usage and operating costs. Similarly, Todde et al. (2016) evaluated 285 conventional dairy farms in Italy and found that fan system power had a standard deviation of 40 to $93 \%$ depending on their level of intensive management, mechanization, and size.

In an energy audit of 32 dairy facilities across central and northern New York, Ludington and Johnson (2003) found ventilation to be $22 \%$ of the total energy usage on the farm - the third largest category. Energy conservation methods were identified for other areas of the farm, which could reduce energy use of milk plate coolers by $33 \%$, vacuum pumps by $47 \%$, and lighting by $17 \%$, but no conservation methods were identified for the ventilation systems. The data in Figure 5 suggest that controlling for fan choice can significantly reduce energy usage on all systems.

Ideally, when selecting a fan, various options should be evaluated at the ventilation system's operating point, and the fan that provides the most $\mathrm{m}^{3} / \mathrm{h}$ per $\mathrm{W}$ would be selected. Fan VER is a function of its design, and field evaluations have shown that fans that have not been tested by the Air Movement and Control
Association can have ratings $50 \%$ less than what the manufacturer advertises (Bodman and Shelton, 1995).

Agricultural fans are also typically exposed to a very humid and dirty environment, making maintenance a constant requirement. Fans can lose 40 to $50 \%$ of their efficiency due to poor maintenance, and even a 3-mm dust buildup on the fan blades and shutters can reduce efficiency by as much as 30\% (Bodman and Shelton, 1995). Similarly, wet, caked louvers on fans were found to reduce fan discharge by $24 \%$ (Person et al., 1979). A $30 \%$ decrease in efficiency would reduce the design ventilation rate for the $8 \mathrm{CRO}$ system from $53 \mathrm{ACH}$ to $37 \mathrm{ACH}$. The model did not estimate the cost of maintaining each type of fan; however, Ferreira et al. (2016) suggested that maintenance would cost $\$ 15$ per fan per year. Using this estimate, the mean, minimum, and maximum maintenance cost from all systems and stochastic observations $(\mathrm{n}=109)$ was $\$ 0.90, \$ 0.40$, and $\$ 2.20$ per stall per year, respectively. The mean maintenance cost is much smaller than a potential loss of 30 to $50 \%$ efficiency in the ventilation system. However, fan maintenance is a common recommendation that is often poorly prioritized by producers.

\section{Operating Costs: Parametric Module}

Ventilation System Operating Decisions. All of the estimated operating cost changes due to ramping

Table 2. Distribution of ventilation operating costs evaluating a single system rating (no variance in energy price or fan performance) in US\$ $(\mathrm{kW} \cdot \mathrm{h})$ per stall per year ${ }^{1}$

\begin{tabular}{|c|c|c|c|c|}
\hline Parameter & Mean & Median & Minimum & Maximum \\
\hline \multicolumn{5}{|l|}{ Location } \\
\hline Arizona & $82.76(827.6)$ & $81.92(819.2)$ & $19.38(193.8)$ & $191.30(1,913.0)$ \\
\hline California & $62.77(627.7)$ & $56.06(560.6)$ & $0.00(0.0)$ & $164.70(1,647.0)$ \\
\hline Florida & $73.46(734.6)$ & $68.84(688.4)$ & $0.33(3.3)$ & $188.40(1,884.0)$ \\
\hline Minnesota & $32.58(325.8)$ & $27.99(279.9)$ & $0.00(0.0)$ & $95.49(954.9)$ \\
\hline Pennsylvania & $41.08(410.8)$ & $36.04(360.4)$ & $0.00(0.0)$ & $117.60(1,176.0)$ \\
\hline Washington & $28.19(281.9)$ & $22.85(228.5)$ & $0.00(0.0)$ & $97.71(977.1)$ \\
\hline Wisconsin & $35.85(358.5)$ & $31.59(315.9)$ & $0.00(0.0)$ & $101.90(1,019.0)$ \\
\hline \multicolumn{5}{|c|}{ Temperature profile } \\
\hline Minimum & $29.39(293.9)$ & $23.28(232.8)$ & $0.0(0.00)$ & $102.10(1,201.0)$ \\
\hline Average & $51.46(514.6)$ & $43.87(438.7)$ & $0.0(0.00)$ & $157.30(1,573.0)$ \\
\hline Maximum & $72.02(720.2)$ & $62.32(623.2)$ & $12.86(128.6)$ & $191.30(1,913.0)$ \\
\hline \multicolumn{5}{|c|}{ Summer set point $\left({ }^{\circ} \mathrm{C}\right)$} \\
\hline 16.7 & $59.89(598.9)$ & $51.38(513.8)$ & $0.00(0.0)$ & $191.30(1,913.0)$ \\
\hline 18.3 & $55.83(558.3)$ & $49.11(491.1)$ & $0.00(0.0)$ & $1,875.0(187.50)$ \\
\hline 20.0 & $51.72(517.2)$ & $45.69(456.9)$ & $0.00(0.0)$ & $179.70(1,797.0)$ \\
\hline 22.2 & $45.66(456.6)$ & $38.23(382.3)$ & $0.00(0.0)$ & $164.40(1,644.0)$ \\
\hline 23.9 & $41.69(416.9)$ & $34.24(342.4)$ & $0.00(0.0)$ & $154.50(1,545.0)$ \\
\hline \multicolumn{5}{|c|}{ Ramping function } \\
\hline Linear & $61.38(613.8)$ & $54.75(547.5)$ & $11.67(116.7)$ & $191.30(1,913.0)$ \\
\hline Staged & $60.43(604.3)$ & $51.56(515.6)$ & $11.50(115.0)$ & $191.30(1,913.0)$ \\
\hline Exponential & $55.44(554.4)$ & $47.66(476.6)$ & $8.67(86.7)$ & $191.30(1,913.0)$ \\
\hline
\end{tabular}

${ }^{1}$ Energy price was $0.10 \$ / \mathrm{kW} \cdot \mathrm{h} ; \mathrm{n}=2,205$ parametric evaluations by location, temperature profile, temperature set point, and ramping function where the variable at the row is maintained constant while the rest are allowed to vary. Building costs are not included. 
function, summer temperature set point, location, and temperature profile - the parametric components of the model - for a single stochastic iteration of energy price and system rating are summarized in Table 2.

Location. When examining operating cost differences across different daily temperature ranges, a ventilation system would require on average $\$ 51.50$ (515 $\mathrm{kW} \cdot \mathrm{h})$ per stall per year to run but may vary from $\$ 29.40(294 \mathrm{~kW} \cdot \mathrm{h})$ to $\$ 72.00(720 \mathrm{~kW} \cdot \mathrm{h})$ per stall per year between the minimum and maximum temperature profiles. Hotter climates (AZ, CA, and FL) had a mean of $\$ 62.80(628 \mathrm{~kW} \cdot \mathrm{h})$ to $\$ 82.80(828 \mathrm{~kW} \cdot \mathrm{h})$ per stall per year, whereas the milder climates (PA, MN, WI, and WA) had a mean of $\$ 28.20(282 \mathrm{~kW} \cdot \mathrm{h})$ to $\$ 41.10$ (411 $\mathrm{kW} \cdot \mathrm{h}$ ) per stall per year - approximately half that of warmer regions. The average costs for the 7 ventilation systems operating under 7 different locations, excluding variations in energy price, fan capacity, and VER and allowing for temperature set point, temperature profile, and ramping function to vary, are shown in Figure 6.

The HYB40 and TUN40 were generally the most costly barns to operate, but the difference was much smaller for more temperate regions than in hotter climates. The flexibility offered by these facilities, especially the HYB40, is attractive for cooler regions but likely not economically justifiable for hotter regions of the United States. On average, the capital cost of the ventilation systems was $26 \%$ of the operating costs of the ventilation system over $10 \mathrm{yr}$ in WA (mildest) and $11 \%$ in FL (hottest). Selecting higher efficiency fans, although typically more expensive upfront, will likely result in higher savings over time. Regardless of regional variations, the cost of ventilation lies mainly in the operating costs of the fans.

Table 3 shows the operating costs for the 7 ventilation systems in Madison, Wisconsin, compared with Jacksonville, Florida, using a summer temperature set point of $18.0^{\circ} \mathrm{C}$, linear ramping, and annual temperature profile of average and including variations in fan capacity and VER. In milder climates, the cost difference between the average mechanical systems was small, but in hotter climates the differences between the mechanical systems increased such that the cost of the $16 \mathrm{CRO}$ facility appeared advantageous and was even similar to or less than the cost of natural ventilation.

As expected, the barns with the least energy use were the NAT1 and NAT2 barns, but the $16 \mathrm{CRO}$ came very close to the NAT2 barn at $303.4 \mathrm{~kW} \cdot \mathrm{h}(\$ 30.34)$ per stall per year. The energy use for the other mechanical systems was very similar at $553.6 \mathrm{~kW} \cdot \mathrm{h}(\$ 55.36)$ to $695.2 \mathrm{~kW} \cdot \mathrm{h}(\$ 69.52)$ per stall per year in Madison, Wisconsin.

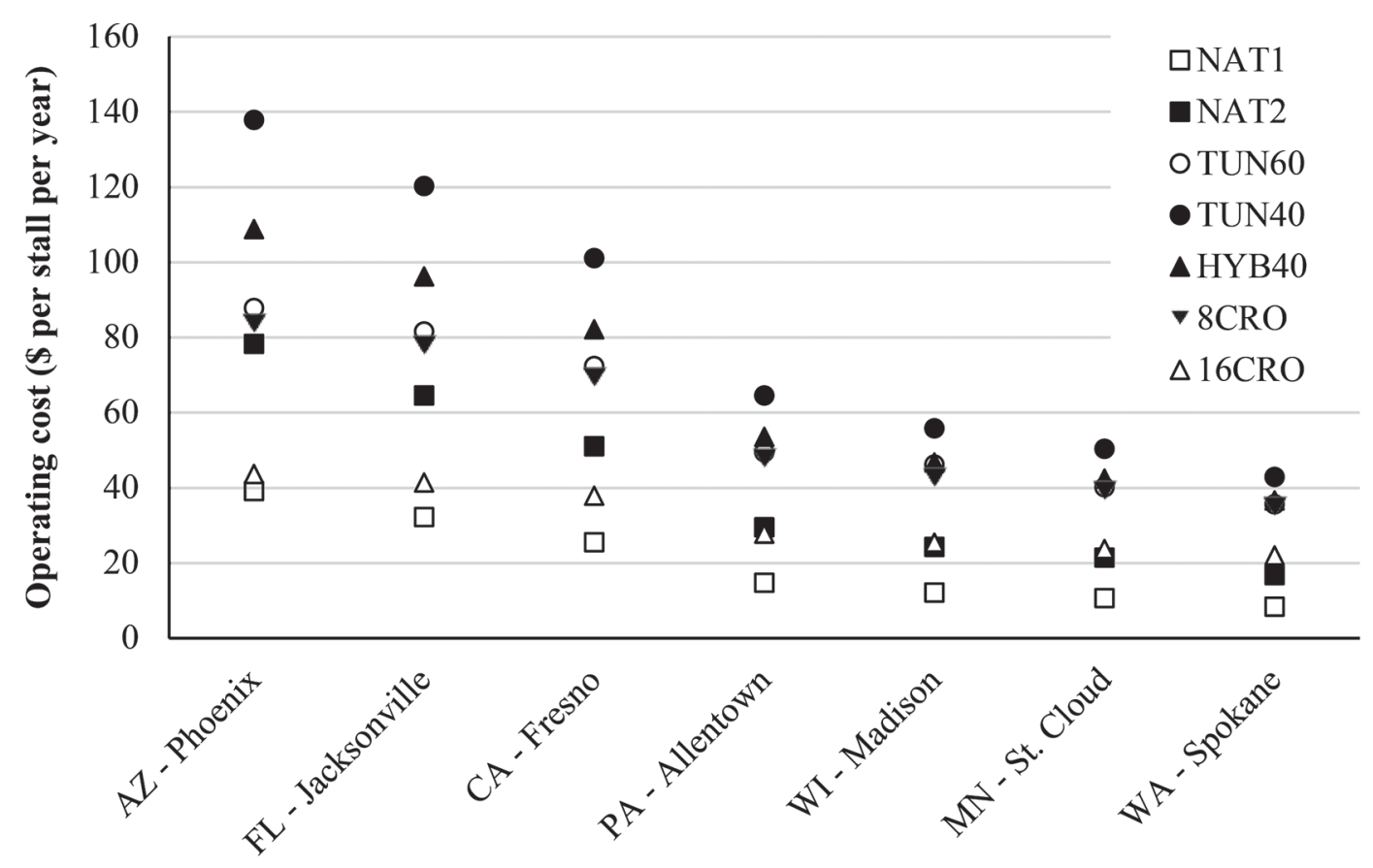

Figure 6. Average location operating costs of 7 ventilation systems without stochastic variation corrected to an energy price of $\$ 0.10 / \mathrm{kW} \cdot \mathrm{h}$ and showing 45 parametric observations where temperature profile, ramping, and temperature set point vary. Natural ventilation with fans spaced every $14.6 \mathrm{~m}$ (NAT1) and $7.3 \mathrm{~m}$ (NAT2). Tunnel ventilation at 60 (TUN60) air changes per hour (ACH) and 40 (TUN40) ACH with panel fans every $7.3 \mathrm{~m}$. Hybrid (HYB40) ventilation (40 ACH) using louvered fans every $18.3 \mathrm{~m}$. Eight-row (8CRO) and 16-row (16CRO) crossventilated systems designed for $2.5 \mathrm{~m} / \mathrm{s}$ below the baffle. 


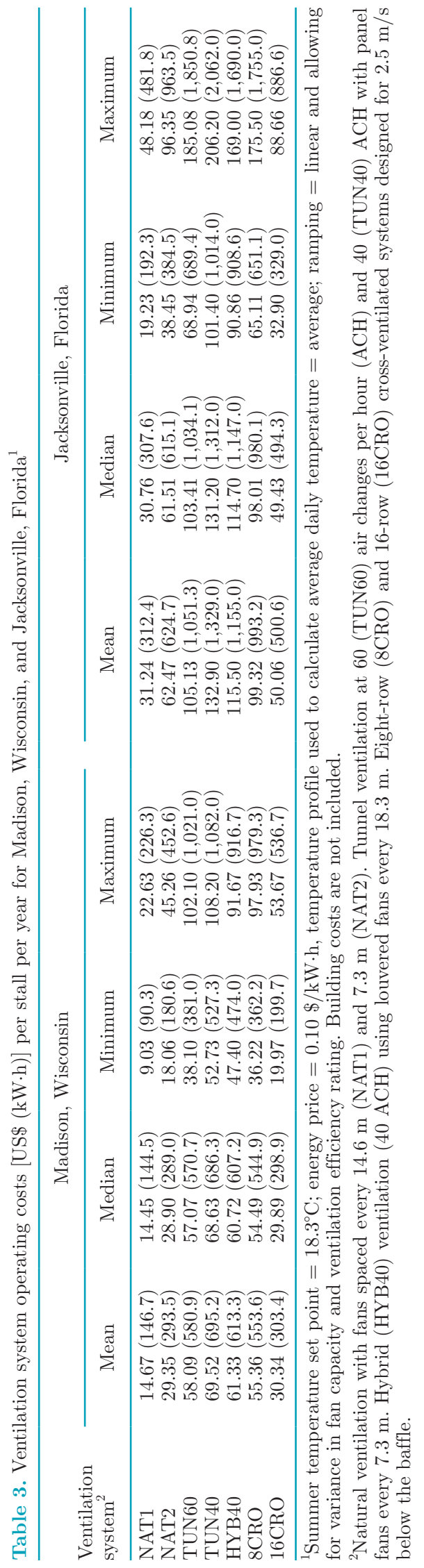

Natural systems are commonly assumed to cost less to operate than mechanical systems, and although this study arrives at the same conclusion for facilities with 1,008 stalls, Tyson (2008) had the opposite result. In an evaluation of the cost of operating a naturally ventilated and a tunnel-ventilated barn in Pennsylvania, the author found that the natural ventilation system (for 1,000 lactating cows) had a yearly energy use of $\$ 42.90$ (429 kW.h) per stall per year, whereas a tunnel ventilation system designed at $48 \mathrm{ACH}$ used $\$ 22.30$ $(223 \mathrm{~kW} \cdot \mathrm{h})$ per stall per year. In his analysis, Tyson (2008) defined the natural barn as having a linear staged ramping function to transition between seasons, whereas the tunnel barn had natural ventilation below $15.5^{\circ} \mathrm{C}$. In other words, the natural barn incorporated elements of mechanical ventilation (fans and ramping functions), whereas the tunnel barn behaved more as a passive hybrid, fully incorporating natural ventilation in mild and cold temperatures. That natural barns cost less to operate than mechanical barns has been a standard industry assumption (Atkins et al., 2015). However, our results show that these assumptions do not necessarily hold for larger facilities across different fan selections and operational logistics.

Summer Temperature Set Point. The average energy use and operating costs for the summer temperature set points were $\$ 59.90(599 \mathrm{~kW} \cdot \mathrm{h}), \$ 55.80$ (558 kW·h), \$51.70 (517 kW·h), \$45.70 (457 kW·h), and $\$ 41.70(417 \mathrm{~kW} \cdot \mathrm{h})$ per stall per year for the set points $16.7,18.3,20.0,22.2$, and $23.9^{\circ} \mathrm{C}$, respectively. When shifting the set point from 22.2 to $20.0^{\circ} \mathrm{C}$, the systems operated $37 \mathrm{~d}$ longer, on average across all locations, under summer ventilation rate - an average increase of energy use of $\$ 6.00(60 \mathrm{~kW} \cdot \mathrm{h})$ per stall per year. Further decreasing the set point to $18.3^{\circ} \mathrm{C}$ would increase the days operating under summer ventilation days by 18 , meaning an additional $\$ 4.10(41 \mathrm{~kW} \cdot \mathrm{h})$ per stall per year, or a total of $\$ 37.3$ million (373 million $\mathrm{kW} \cdot \mathrm{h}$ ) for the 2015 US lactating dairy herd (USDA ERS, 2016). Due to the economic losses related to the effects of heat stress on lameness, health, reduced milk production, and subfertility (West, 2003; De Rensis and Scaramuzzi, 2003; Cook et al., 2007), reducing the set point to $18.3^{\circ} \mathrm{C}$ is economically sound if the system mitigates the losses sustained. Nationally, heat stress losses for the US dairy herd have been estimated at almost $\$ 900$ million per year (St-Pierre et al., 2003) even after introducing optimal cooling strategies at the time. As energy prices continue to increase, future research needs to quantify the economic losses of poorly ventilated dairy housing facilities to reduce energy consumption while maintaining a healthy environment for cows.

Ramping Function. Linear and staged ramping functions had similar average energy use at $\$ 61.40$ (614 
$\mathrm{kW} \cdot \mathrm{h})$ and $\$ 60.40(604 \mathrm{~kW} \cdot \mathrm{h})$ per stall per year, respectively. The exponential ramping function had an average energy use of $\$ 55.40(554 \mathrm{~kW} \cdot \mathrm{h})$ per stall per year. The ramping function to transition between winter and summer, and vice versa, has the potential to save, on average across all systems, $\$ 6.00(60 \mathrm{~kW} \cdot \mathrm{h})$ per stall per year due to reduced system operating times. Atkins et al. (2015) found that using variable-speed fans can reduce power by $\$ 7.60(76 \mathrm{~kW} \cdot \mathrm{h})$ per stall per year from operating fans at a higher efficiency ratio due to the reduced operating frequency. As sensor technology continues to improve, the idea of increased telemetry in the barn has become more popular. One question is whether the current ventilation system could be better controlled with increased telemetry or by monitoring the cow herself instead of relying on temperature measurements in the barn alone. Incorporating variablespeed fans and an ideal ventilation ramping function due to increased telemetry has the potential to save around $\$ 13.60(136 \mathrm{~kW} \cdot \mathrm{h})$ per stall per year, which is the opportunity cost for optimizing ventilation through sensor systems. In regions with higher energy price $(\$ 0.16 / \mathrm{kW} \cdot \mathrm{h})$ such as Germany (Eurostat, 2016), the margin increases to $\$ 21.8$ per stall per year, making such advanced approaches more economically viable.

\section{CONCLUSIONS}

This study aimed to quantify the costs of selecting a ventilation system for lactating adult dairy cattle as well as the effect of changing control logistics on operating cost and energy use. It was found that crossventilated barns benefit from economies of scale and had similar costs as natural barns in 2,000-stall facilities. On average, mechanical systems in 1,000-stall facilities cost approximately twice as much to operate as natural systems, and operating costs in hotter climates were approximately double those in milder climates in the United States. Improvement in energy use through improved control technology for ventilation systems is important, but the dairy industry is at a stage where ensuring that the most efficient fan is used for each system and that a proper maintenance protocol is being followed outweighs other energy-saving methodologies. Many of the potential savings in energy use were overshadowed by fan selection, which had the largest effect on the variance of operational costs.

\section{ACKNOWLEDGMENTS}

We acknowledge Bayland Buildings Inc. (Hobart, WI) and J\&D Manufacturing (Eau Claire, WI) for their help in obtaining capital costs and industry trends as well as Courtney Halbach at The Dairyland Initiative
(Madison, WI) for her extensive review and editing of this manuscript.

\section{REFERENCES}

Armstrong, D. V. 1994. Heat stress interaction with shade and cooling. J. Dairy Sci. 77:2044-2050.

Atkins, I., C. Y. Choi, and B. Holmes. 2015. Dairy cooling: The benefits and strategies. Accessed Dec. 2017. http://www.schaeferventilation .com/support-resources/dairy-resources/.

Bailey, T., J. Sheets, D. McClary, S. Smith, and A. Bridges. 2016. Heat abatement guide. Accessed Dec. 2017. http://www.ag.k-state.edu/ ffa/2018_rules/dairy_resources/Elanco\%20Heat\%20Abatement $\% 20$ Guide.pdf.

Balakrishnan, N., and V. B. Nevzorov. 2003. A Primer on Statistical Distributions. Wiley, Hoboken, NJ.

Bodman, G. R., and D. P. Shelton. 1995. Ventilation fans: Performance. Guide G95-1242-A. Cooperative Extension Service, University of Nebraska-Lincoln.

Brotzman, R. L., N. B. Cook, K. Nordlund, T. B. Bennett, A. Gomez Rivas, and D. Döpfer. 2015. Cluster analysis of dairy herd improvement data to discover trends in performance characteristics in large Upper Midwest dairy herds. J. Dairy Sci. 98:3059-3070.

Bucklin, R. A., D. R. Bray, J. G. Martin, L. Carlos, and B. Carvalho. 2009. Environmental temperatures in Florida dairy housing. Appl. Eng. Agric. 25:727-735.

Collier, R. J., R. B. Zimbelman, R. P. Rhoads, M. L. Rhoads, and L. H. Baumgard. 2011. A re-evaluation of the impact of temperature humidity index (THI) and black globe humidity index (BGHI) on milk production in high producing dairy cows. Pages 113-125 in Proc. Western Dairy Management Conf., Reno, NV. Accessed May 2017. http://wdmc.org/2011/2011\%20Proceedings-Complete.pdf.

Cook, N. B., R. L. Mentink, T. B. Bennett, and K. Burgi. 2007. The effect of heat stress and lameness on time budgets of lactating dairy cows. J. Dairy Sci. 90:1674-1682.

De Rensis, F., and R. J. Scaramuzzi. 2003. Heat stress and seasonal effects on reproduction in the dairy cow: A review. Theriogenology 60:1139-1151.

Delignette-Muller, M. L., and C. Dutang. 2015. fitdistrplus: An R package for fitting distributions. J. Stat. Softw. 64:1-34.

Eurostat. 2016. Electricity price statistics: Electricity prices for industrial consumers. Accessed Apr. 2017. http://ec.europa.eu/eurostat/ statistics-explained/index.php/Electricity_price_statistics.

Ferreira, F. C., R. S. Gennari, G. E. Dahl, and A. De Vries. 2016. Economic feasibility of cooling dry cows across the United States. J. Dairy Sci. 99:9931-9941.

Gooch, C. A., and R. R. Stowell. 2003. Tunnel ventilation for freestall facilities-Design, environmental conditions, cow behavior, and economics. Pages 227-234 in Fifth International Dairy Housing Proceedings, Fort Worth, TX. K. A. Janni, ed. ASAE, St. Joseph, MI.

Holmes, B., N. Cook, T. Funk, R. Graves, D. Kammel, D. J. Reinemann, and J. M. Zulovich. 2013. Dairy Freestall Housing and Equipment. 8th ed. MidWest Plan Service, Ames, IA.

Kammel, D. W. 2015. Building costs estimates-Dairy modernization. Accessed Jun. 2016. http://fyi.uwex.edu/dairy/files/2015/11/ Building-Cost-Estimates-Dairy-Modernization.pdf.

Ludington, D., and E. Johnson. 2003. Dairy farm energy audit summary. Accessed Jun. 2016. https://www.nyserda.ny.gov/-/media/ Files/Publications/Research/Energy-Audit-Reports/dairy-farm -energy.pdf.

NOAA (National Oceanic and Atmospheric Administration). 2017. Climate data online. Accessed Mar. 2017. https://www.ncdc.noaa .gov/cdo-web/.

OSHA (Occupational Safety and Health Administration). 1970. Occupational safety and health standards: Safety and health regulations for construction. Standard no. 1926.300(b)(5). Accessed Dec. 2017. https://www.osha.gov/pls/oshaweb/owadisp.show_document?p _table=STANDARDS\&p_id $=10688 \# 1910.212(\mathrm{a})(3)$. 
Person, H. L., L. D. Jacobson, and K. A. Jordan. 1979. Effect of dirt, louvers and other attachments on fan performance. Trans. Am. Soc. Agric. Eng. 22:612-616.

R Core Team. 2016. R: A Language and Environment for Statistical Computing. R Foundation for Statistical Computing, Vienna, Austria.

Smith, J. F., B. J. Bradford, J. P. Harner, J. C. Potts, J. D. Allen, M. W. Overton, X. A. Ortiz, and R. J. Collier. 2016. Short communication: Effect of cross ventilation with or without evaporative pads on core body temperature and resting time of lactating cows. J. Dairy Sci. 99:1495-1500.

Smith, J. F., J. P. Harner, M. de Haro Marti, J. Zulovich, C. Fulhage, B. Hetcher, and K. Dhuyvetter. 2007. Comprehensive evaluation of a low-profile cross-ventilated freestall barn. Pages 127-148 in Proc. Western Dairy Management Conf., Reno, NV. Accessed May 2017. http://wdmc.org/2007/WDMC\%202007.pdf.

St-Pierre, N. R., B. Cobanov, and G. Schnitkey. 2003. Economic losses from heat stress by US livestock industries. J. Dairy Sci. 86(Suppl.):E52-E77.

Stowell, R. R., C. A. Gooch, and W. G. Bickert. 2003. Design parameters for hot-weather ventilation of dairy housing: A critical review. Pages 218-226 in Fifth International Dairy Housing Proc., Fort Worth, TX. K. A. Janni, ed. ASAE, St. Joseph, MI

The Dairyland Initiative. 2016. Adult cow housing. Accessed Jun. 2016. https://thedairylandinitiative.vetmed.wisc.edu/home/ housing-module/adult-cow-housing/.
Todde, G., L. Murgia, M. Caria, and A. Pazzona. 2016. A multivariate statistical analysis approach to characterize mechanization, structural and energy profile in Italian dairy farms. Energy Rep. $2: 129-134$

Todde, G., L. Murgia, M. Caria, and A. Pazzona. 2017. Dairy Energy Prediction (DEP) model: A tool for predicting energy use and related emissions and costs in dairy farms. Comput. Electron. Agric. $135: 216-221$.

Tyson, J. T. 2008. Heat abatement techniques in dairy housing in the Northeast. MS Thesis. Department of Agricultural and Biological Engineering, Pennsylvania State University, University Park.

USDA ERS (USDA Economic Research Service). 2016. Milk cows and production by state and region. Accessed Mar. 2017. https://www .ers.usda.gov/data-products/dairy-data/.

USDA ERS (USDA Economic Research Service). 2017. Milk production and factors affecting supply. Accessed Mar. 2017. https:// www.ers.usda.gov/data-products/dairy-data/.

West, J. W. 2003. Effects of heat stress on production in dairy cattle. J. Dairy Sci. 86:2131-2144.

Yeck, R. G., and R. E. Stewart. 1959. A ten-year summary of the psychoenergetic laboratory dairy cattle research at the University of Missouri. Trans. Am. Soc. Agric. Eng. 2:71-77. 